\title{
Blended-Problem-Based Learning: How its impact on students' critical thinking skills?
}

\author{
Marheny Lukitasari a,1, Indah Purnamasari a,2, Sri Utami a,3, Akhmad Sukri b,4," \\ a Department of Biology Education, Faculty of Teacher Training and Education, Universitas PGRI Madiun, Jl. Setia Budi No. 85, \\ Madiun, East Java, 63118, Indonesia \\ ${ }^{b}$ Department of Biology Education, Faculty of Mathematics and Science Education, Universitas Pendidikan Mandalika, Jl. Pemuda \\ No. 59A, Dasan Agung Baru, Mataram, West Nusa Tenggara Province, 83125, Indonesia \\ marheny@unipma.ac.id; 2 indah010897@gmail.com; ${ }^{3}$ sriutami@unipma.ac.id; ${ }^{4}$ ahmadsukri.bio@gmail.com* \\ ${ }^{*}$ Corresponding author
}

\begin{tabular}{|c|c|}
\hline ARTICLE INFO & ABSTRACT \\
\hline $\begin{array}{l}\text { Article history } \\
\text { Selected paper from The 1st } \\
\text { National Conference on Education, } \\
\text { Social Science, and Humaniora } \\
\text { (NC-ESSH), Mataram, West Nusa } \\
\text { Tenggara-Indonesia, August 24, } \\
2019 \text { (ocs.litpam.org/index.php/ } \\
\text { index). Peer-reviewed by } \\
\text { NC_ESSH Committee and Editorial } \\
\text { Board of JPBI (Jurnal Pendidikan } \\
\text { Biologi Indonesia) }\end{array}$ & $\begin{array}{l}\text { Critical thinking skills are one of the four main competencies that must be empowered in } \\
\text { the } 21 \text { st-Century Learning. This study aimed to describe students' critical thinking skills } \\
\text { through the application of blended-problem-based learning (PBL) in the Cell Biology } \\
\text { course. The data sources of this research were } 28 \text { students who were taking Cell } \\
\text { Biology Course in Department of Biology Education, Universitas PGRI Madiun. The } \\
\text { research instruments used were 1) observation sheet, 2) interview guidelines, and } 3 \text { ) } \\
\text { critical thinking skills test. The study was designed by applying blended-PBL on } 12 \\
\text { topics. The data analysis was performed in descriptive qualitative. The results showed } \\
\text { that the application of blended-PBL was able to train students to improve their critical } \\
\text { thinking skills in term of how to answer the test given. However, further studies need to } \\
\text { be done with a wider number of samples and material scope to get more } \\
\text { comprehensive information. }\end{array}$ \\
\hline $\begin{array}{l}\text { Received October 15, } 2019 \\
\text { Revised October 30, } 2019 \\
\text { Accepted November 19, } 2019\end{array}$ & \\
\hline $\begin{array}{l}\text { Published November 30, } 2019 \\
\text { Keywords } \\
\text { blended learning } \\
\text { critical thinking skills } \\
\text { problem-based learning }\end{array}$ & $\begin{array}{l}\text { Copyright } \odot \text { 2019, Lukitasari et al } \\
\text { This is an open access article under the CC-BY-SA license }\end{array}$ \\
\hline
\end{tabular}

How to cite: Lukitasari, M., Purnamasari, I., Utami, S. \& Sukri, A. (2019). Blended-Problem-Based Learning: How its impact on students' critical thinking skills? JPBI (Jurnal Pendidikan Biologi Indonesia), 5(3), 425-434. doi: https://doi.org/10.222 19/jpbi.v5i3.10048

\section{INTRODUCTION}

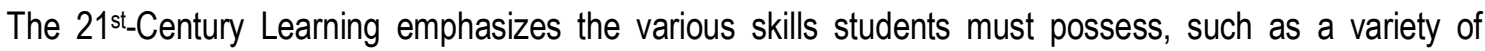
thinking (Dwyer, Hogan, \& Stewart, 2014; Greiff, Niepel, \& Wüstenberg, 2015) and communication skills (Siddiq, Scherer, \& Tondeur, 2016). Among the various thinking skills, critical thinking skills (CTS) and problemsolving are considered as the main essential skills that must be possessed by every student (Dwyer et al., 2014; Schmaltz, Jansen, \& Wenckowski, 2017). CTS included the higher-order thinking skills (HOTS) that is suitable for someone to face the development of the world today (Crowley, 2015). Critical thinkers will have the ability to think scientifically, reflectively and focus on deciding something about what to believe and do (Ennis, 
2011). Furthermore, practicing CTS is an important component that must be considered in higher education institution and needs to be developed especially for undergraduate students (Kumar \& James, 2015).

Stimulating students to think critically is needed in learning and one of the learning models that can sharpen student CTS is Problem-Based Learning (PBL) (Masek \& Yamin, 2011; Temel, 2014). This learning model can train CTS because it actively involves students to solve problems through the stages of the scientific method (Isabekov \& Sadyrova, 2018). PBL meets the characteristics of Student-Centered Learning (Lopes et al., 2020), so that it can encourage students to learn and work cooperatively to practice analytical critical thinking in finding solutions. The advantage of PBL is to familiarize students with overcoming problems through case study simulations in class based on problems of daily life so as to foster social solidarity in discussions (Batdi, 2014). In addition, PBL is able to train students in using various concepts, principles and skills that they have learned to solve the problems encountered (Yew \& Goh, 2016). Based on some of the results of these studies, the implementation of PBL needs to be conducted for various subjects in Higher Education, one of which is the Cell Biology course.

Cell Biology is a compulsory subject in the Biology education study program with abstract concepts which makes it difficult for students to study it (Lukitasari \& Susilo, 2014). The statement was also supported by a report that identified Cell Biology, including courses that were considered difficult by some students majoring in biology (Fauzi \& Fariantika, 2018). Students tend to memorize results rather than study and discover the processes of chemical reactions that occur in cells. Based on the characteristics of the Cell Biology course, students must have the ability to reason logically, think analytically and have a strong imagination. Therefore, the application of PBL is expected could to improve the competence of students in Cell Biology course.

However, despite having many advantages, PBL was identified as having weaknesses caused by various reasons (Ates \& Eryilmaz, 2011). One of the challenges that sometimes becomes the main obstacle in implementing PBL is time. Earlier reports inform that from the teacher's perspective, PBL activities require a lot of time allocation (Blackwell \& Roseth, 2018). These findings are in line with statements in other references which state that PBL requires more time allocation than traditional learning (Marta, 2011). In addition, the activity of delivering knowledge cannot be done by the teacher so that it becomes a problem for the teacher (Pagander \& Read, 2014). Furthermore, evaluation activities are still difficult for teachers to implement when they implement PBL (Ates \& Eryilmaz, 2011; Pagander \& Read, 2014).

To minimize PBL weaknesses and optimize their effectiveness, various studies have also examined the effect of blended learning during PBL implementation. Combining face to face with online learning have reported could to improve students' HOTS (Lukitasari, Handhika, \& Murtafiah, 2018; Lukitasari, Handhika, \& Murtafiah, 2016). Furthermore, one study reported that by integrating PBL with online learning, motivation and scientific communication of students could increase (Suwono \& Dewi, 2019). The implementation of PBL is more efficient when the combination is carried out (Ammann, Vignoli, \& Kaap-Fröhlich, 2019). The results of the meta-analysis also inform that blended-PBL is more effective than traditional PBL (Car et al., 2019). BlendedPBL was also reported to be more effective in creating active learning in Asian students (Shimizu, Nakazawa, Sato, Wolfhagen, \& Könings, 2019).

Several studies on blended-PBL have been carried out by other researchers. However, this research is still limited to a variety of specific research subjects. In the Biology Education field, research subjects in previous reports also often use high school students (Suwono \& Dewi, 2019). Whereas various studies in higher education examining blended-PBL implementation often involve medical students (Car et al., 2019) or health (Ammann et al., 2019; de Jong, Krumeich, \& Verstegen, 2017). In addition to the limitations of the research subject, the competencies analyzed in the various studies are also limited to students' scientific motivation and communication (Suwono \& Dewi, 2019) and the mastery of knowledge (Car et al., 2019; Shimizu et al., 2019). Therefore, the purpose of this study was to examine the impact of Blended-PBL on students' CTS.

\section{METHOD}

The research was carried out in the Biology Education study program, the Teaching and Education Faculty of the Universitas PGRI Madiun in the Cell Biology course. The study was conducted from April to June 2019. The source of the research data was the second semester students of Biology Education Study Program as many as 28 students. The study was conducted by means of observation during learning activities by using blended-PBL for 12 subjects in the Cell Biology course. Google Classroom (GC) was a Learning Management System (LMS) chosen to accommodate online learning.

The research instruments used were: 1) questionnaire, to find out the implementation of blended learning in terms of (a) attention, (b) relevance, (c) self-confident, (d) information Literacy, (e) student attitudes toward Blended-PBL, and (f) student evaluation about Blended-PBL. The questionnaire contained 20 statements and 
had a range of scores from 1-5 which was then converted into the following percentage form $(0-20 \%=$ Very Bad, $21-40 \%=$ Poor, $41-60 \%=$ Enough, $61-80 \%=$ Good, and $81-100 \%=$ Very Good). Questionnaire was given to students with high and low academic ability. This step was conducted to find a comprehensive picture of how students respond to the implementation of blended learning for all academic levels; 2) interview guidelines, to confirm the results of working on a critical thinking test; 3 ) documentation, results of working on students' critical thinking skills; and 4) CTS test, to measure students' critical thinking skills in the form of 10 multiple choice questions and essays for 3 questions and is applied to pretest and posttest.

The test was arranged based on 5 aspects of CTS according to Ennis (2011) which were elaborated into 12 indicators. Pretest results are classified into high and low categories based on the scoring rubric of critical thinking skills developed by Zubaidah, Corebima, and Mistianah (2015), and then compared with the posttest results. Aspects and indicators of CTS test and the implementation of blended-PBL as shown in Table 1. Next, the data analysis was done descriptively to describe the condition of students' critical thinking skills after applying blended-PBL lectures in the Cell Biology course.

Table 1. CTS aspects and indicators as well as blended learning activity in this study

\begin{tabular}{|c|c|c|c|c|}
\hline No. & CTS aspects & CTS indicators & Topics & Learning form \\
\hline \multirow[t]{3}{*}{1.} & \multirow{3}{*}{$\begin{array}{l}\text { Provide a simple } \\
\text { explanation }\end{array}$} & Focus the question & Cell membrane & face to face \\
\hline & & $\begin{array}{l}\text { Ask and answer questions that require } \\
\text { challenges }\end{array}$ & $\begin{array}{l}\text { Endomembrane System } \\
\text { and Structure } \\
\text { Mitochondrial Function }\end{array}$ & $\begin{array}{c}\text { Online } \\
\text { face to face }\end{array}$ \\
\hline & & Analyze arguments & Cytoskeleton & Online \\
\hline 2. & $\begin{array}{l}\text { Develop basic } \\
\text { skills }\end{array}$ & $\begin{array}{l}\text { Observation and consider the results of } \\
\text { the observation report }\end{array}$ & Cell Cycle & \\
\hline \multirow[t]{4}{*}{3.} & \multirow{4}{*}{$\begin{array}{l}\text { Drawing } \\
\text { conclusions }\end{array}$} & \multirow{2}{*}{$\begin{array}{l}\text { Make decisions and consider the } \\
\text { results }\end{array}$} & Cell Membrane & Online \\
\hline & & & Protein Synthesis & face to face \\
\hline & & \multirow[t]{2}{*}{ Compile and consider induction } & $\begin{array}{l}\text { Cell interactions and } \\
\text { communication }\end{array}$ & face to face \\
\hline & & & Cell Cycle & Online \\
\hline \multirow[t]{2}{*}{4.} & \multirow{2}{*}{$\begin{array}{l}\text { Provide further } \\
\text { explanation }\end{array}$} & Identifying assumptions & Genetic Material & Online \\
\hline & & Identify terms and consider definitions & Endomembrane System & face to face \\
\hline 5. & $\begin{array}{l}\text { Set strategy and } \\
\text { tactics }\end{array}$ & Determine the action & Genetic Material & Online \\
\hline
\end{tabular}

\section{RESULTS AND DISCUSSION}

$\mathrm{PBL}$ is innovative learning that has the potential to create effective learning. Combining PBL with online learning is indicated could to increase the effectiveness of the learning. Changes in student responses before and after the blended-PBL implementation implemented in this study are presented in Figure 1. The more positive response of students to learning after implementing the blended-PBL is in line with some of the previous reports. Some studies report that PBL is learning that can increase student motivation (Chiang \& Lee, 2016), as well as in blended learning (Afip, 2014). Therefore, combining both of them could to increase student motivation. Increased student motivation to learn is one indication of an increase in students' positive responses to learning (Lai, 2011).

The results of the blended-PBL response questionnaire in the Cell Biology course were seen from 6 aspects namely attention, relevance, self-confident, attitudes and student assessment. Attention aspects have increased and are included in the category of "good". The results is in line with previous study that informed students' response to blended learning is in "high" category (Muis \& Bahri, 2018). Furthermore, the aspect of relevance shows that blended learning is feasible because it has been supported by advances in information and communication technology. High response illustrates that blended learning has the potential to increase student participation in learning. In addition, the application of blended learning is in accordance with the conditions in this era. Then, student responses to aspects of information literacy in the "good" category although there has not been a significant increase. Students are used to using ICT in daily life but are not yet accustomed to learning that integrated with ICT. Students assess that blended-PBL can improve communication and interaction and practice the ability to think critically in solving problems.

The results of the analysis of students' attitudes towards blended-PBL showed that the implementation of this learning responded positively by students. The positive attitude of students towards the implementation of blended-PBL is likely due to the combination of the two learning models so that they can motivate and provide satisfaction with the learning undertaken. This is reinforced by previous research that revealed that the implementation of blended-PBL can improve student motivation, cooperation, and orientation in the learning 
process (Woltering, Herrler, Spitzer, \& Spreckelsen, 2009). This study is strengthened by other studies that reveal that the implementation of PBL combined with blended learning in learning can improve students' positive perceptions (Dewi, 2013).

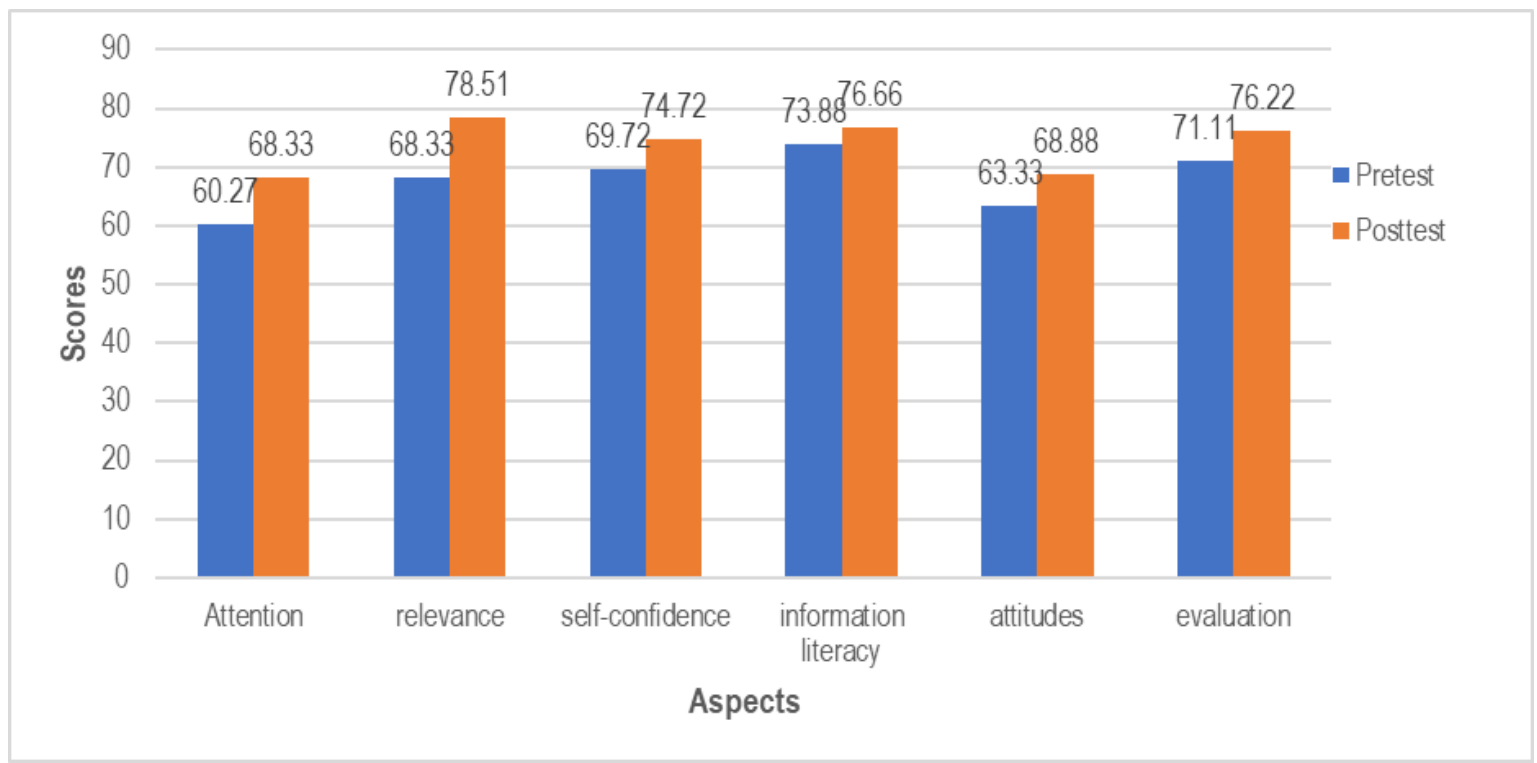

Figure 1. Student responses related to the implementation of cell biology lectures with Blended-PBL

In line with the increase in students' positive responses, their CTS also increased after the blended-PBL was implemented. The results of the scoring of the CTS test that have been carried out in this study are presented in Figure 2. Based on Figure 2, the frequency of students who get a low score has decreased after the blended-PBL is applied. Conversely, the frequency of students who get high scores has increased. Before blended-PBL was applied, $97.01 \%$ of students received a low score and only $2.99 \%$ received a high score. These conditions change after blended-PBL is applied. The frequency of students who received low scores decreased to $47.4 \%$, while those who received high scores increased to $52.60 \%$.

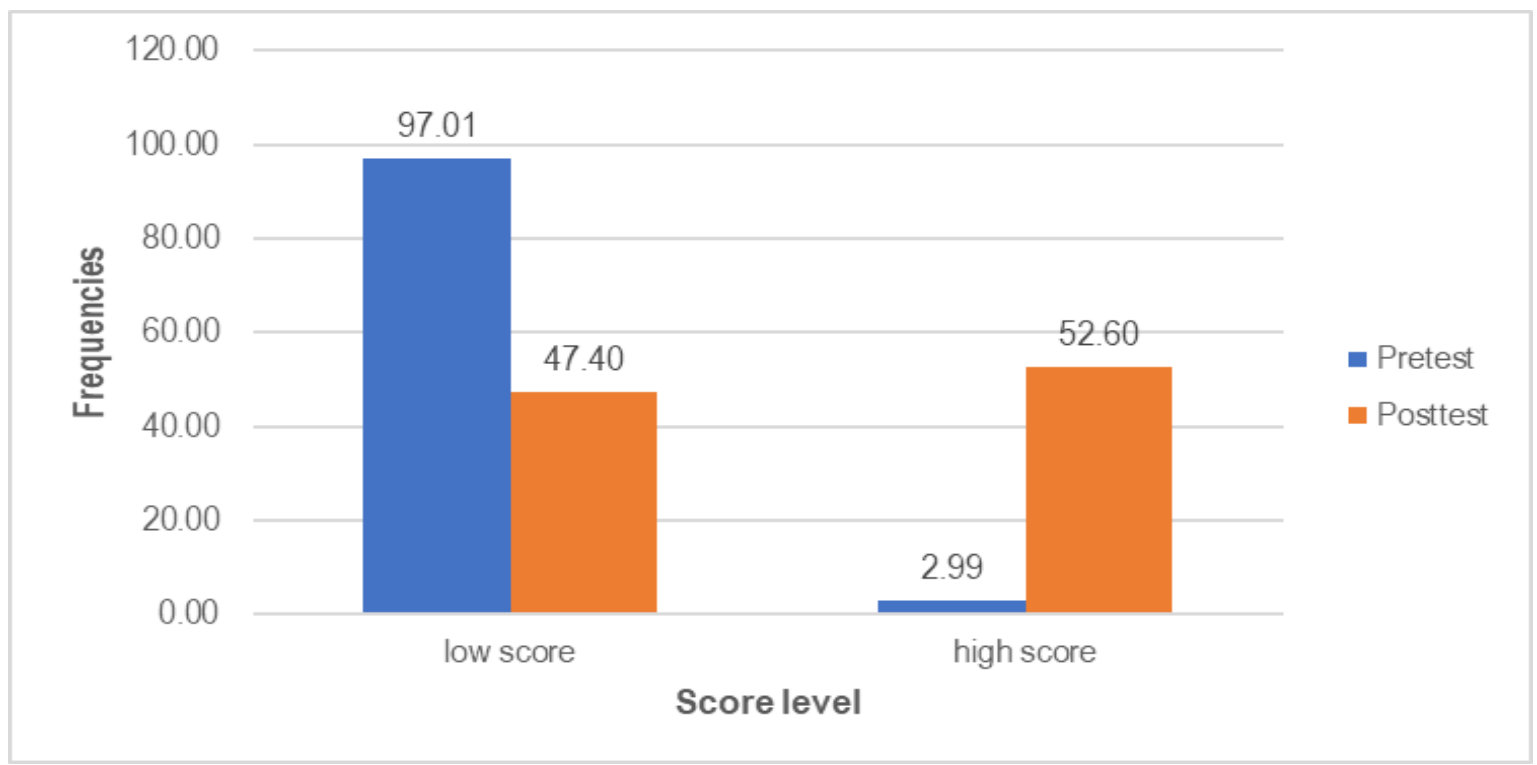

Figure 2. The frequency of CTS students in cell biology courses before and after blended-PBL was implemented

When examined in more depth, the systematic way of thinking contained in the student's answer sentences has also undergone a change. One example of the questions asked aimed at accessing student CTS in this study is as follows:

"In the nucleus of the cell there are two important nucleic acids namely DNA and RNA. In the medical world, DNA is used to determine kinship relationships such as determining the relationship between father and son. 
Based on this explanation, can RNA also be used to determine kinship? Then, describe the structural differences in DNA and RNA and explain the functional relationship of the two nucleic acids!"

Examples of students' answers in answering these questions before the blended-PBL implementation are presented in Figure 3. Figure 3 shows that before the application of blended-PBL, the student's thinking process tends to be unstructured. It appears from the answers presented not accompanied by valid reasons. Students actually understand the context of the question (based on the accuracy of student responses/marked with green, red and blue boxes). However, students do not know the reasons that support or reject the answer. In this case students are weak in providing further explanation which is one aspect of critical thinking.

\section{Esai 3}

- RNA Tidak dapat diqunakan untuk mengetahui hubungan kekerabatan

- Perbedaan E RNA dan DNA

- DNA tersusur atas 2 hel sedangkan RNA satu helix

- Gula DNA pentosa diessiribosa, sedangran RNA pentosa ribosa

- Pada DINA menopunakan timin ifedangkan RNA mengqunakan urasi

- Pada DNA mengqunakan 3 basanitrojen, sedangkan RNA 2 basa nitrogen Hubungan fungsional-DNA dan $M V A=$ Sama<x mentransfer dan menerjemahkan kode geneti

Figure 3. Example of student's answer before the application of blended-PBL

- Hubungan fungrional keduanya adalan ONA untuk menerjemahkan melalui sintesis protein Untuk melakukan itu Diva harus membentuk RNA sebagar pembawa Informasi untuk diterjemahkan di sito plasma dibantu Gleh Ribosom. Karena DNA berada di Nukleus dia mombutuhkan RNA untuk membawa ke sito plasma

\begin{tabular}{|c|c|c|c|c|c|}
\hline Secara Singkat. & DNA & $\rightarrow$ RNA & $\longrightarrow$ & Sintesis & \\
\hline & Beradadi & sebagai & & Protein & \\
\hline & Nukleus & me senger & \multicolumn{3}{|c|}{ di sitoplasma donbantuan } \\
\hline
\end{tabular}

7. Trdak, karena RNA berfungsi untuk sintesic protein saja. Tidak Same dergem DNA पang dapat membawa informasi genetik r vamun pada jenis \#irus tertentu RNA dapat membacua infor masi genetik yano disebut RNA genetik, Contohnya tes RNA dapat mengefahul orang

- Struktur DNA dan RNA

Dita : Double Hellx (Rantai rangkap), memiliki 3 basa nitrogen yaitu Prupin (Adenin, Guanin). Pirimidin (Sitosin, timin) dan gugus posfat, menggunakan gula deoksitibosa, berfung si untik sintesis protein dan menibawa materi gemetik.

RNA : sigle Helix (Rantai funggal), memilike 2 borsa nifrogen vaitu purin (Adenin, Guanin), pirimidin (Sitosin, Urasil), menggunakan gula ribosa. Fungsinya untuk sintesis proteinsaja.

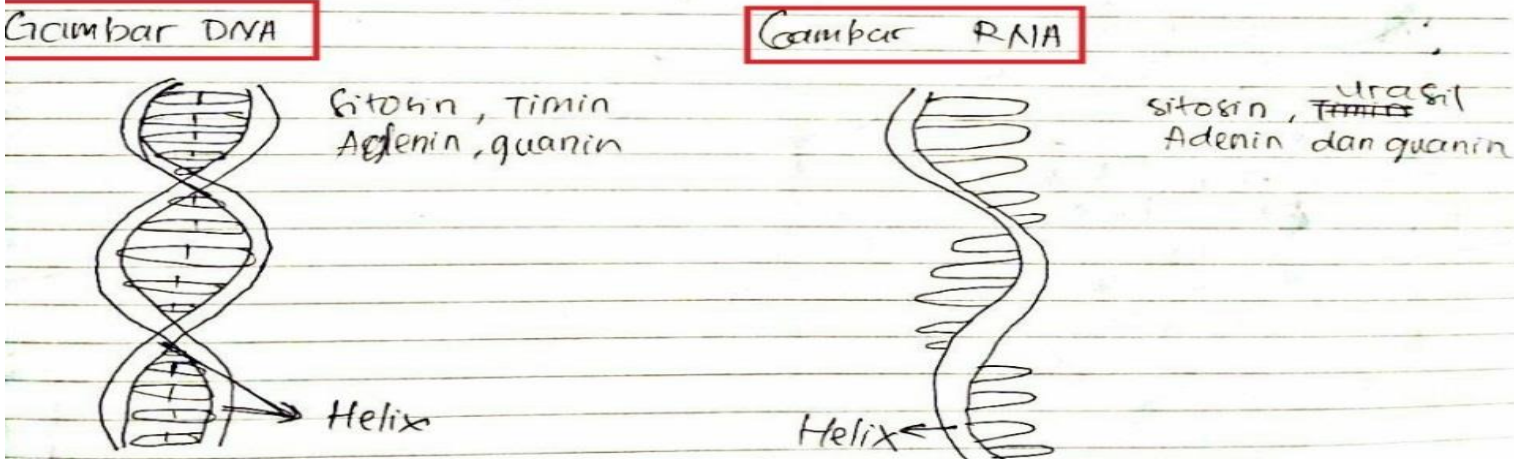

Figure 4. Example of student's answer after the application of blended-PBL 
Next, the examples of student answers after following the blended-PBL are shown in Figure 4. Figure 4 shows students have been able to draw conclusions based on assumptions along with the right reasons in correlating the answers according to the previous statement. This condition was supported by the results of interviews which stated that students claimed to have understood the context of the questions as evidenced by the explanation of coherent answers. However, the results is not in line with one previous study that inform blended learning could not significantly improve CTS of students at Department of Computer and Instructional Technology Education in Turkey (Akyüz \& Samsa, 2009). The difference between the findings from that study with the present study is possible due to the combination of blended learning with PBL that implemented in this present study. Related to the statement, PBL is reported as one of cooperative learning that can empower students' CTS (Gholami et al., 2016; Yew \& Goh, 2016). In this regards, PBL is a recommended to be combined with blended learning to improve the effectiveness of learning in empowering students' thinking skills (Haghparast, Nasaruddin, \& Abdullah, 2014).

Through the application of PBL, students are given the opportunity to get used to solving problems. In PBL, problems will always be presented by the teacher at the beginning of each lesson. Such learning is proven to be effective in improving students' analytical skills (Belecina \& Ocampo, 2018; Ramdiah, Mayasari, Husamah, \& Fauzi, 2018). Through PBL, students will also be directed to be accustomed to inferring the findings obtained after they collect information or supporting data. Such habituation can also train students' skills in solving various problems through a scientific approach (Krishnan, Gabb, \& Vale, 2011; Masek \& Yamin, 2011). In line with this statement, PBL was also said could to improve students' ability to construct their knowledge through investigation (Akcay, 2009; Marra, Jonassen, \& Palmer, 2014)

Practicing critical thinking by addressing problems through the PBL method which is then discussed online provides an opportunity for students to understand the material better. Likewise, in the answers to the results of the post-test it appears that students can provide clarification and then look for and match the appropriate answers to then be concluded correctly. These characteristics as stated Ennis (2011) that the ability to think critically can be reviewed by clarification and seek and assess the truth of information to be concluded.

The role of online discussions conducted through GC is providing comfort condition during learning. Students who have a tendency to lack confidence to ask questions or express opinions in class can be more confident to express it in the GC. Examples of activities carried out in Gc can be seen in Figure 5.

Syamsiatuz Zahro $18 \mathrm{Mei}$
ciri-ciri struktur DNA adalah heliks ganda
(double helix); tersusun atas basa
nitrogen Adenin, Guanin, Timin dan
Sitosin; dan merupakan polimer dari
monomer nukleotida (fosfat-gula
deoksiribosa-basa nitrogen).
http://www.artikelmateri.com/2016/08/
dna-adalah-pengertian-struktur-fungsi-
sifat-replikasi.html?m=1
Her Tanti 18 Mei
Untuk perbedaan secara umum dpat
dilihat gambar di bawah ini
$\underline{\text { https://www.pelajaran.id/2018/12/peng }}$
$\underline{\text { ertian-rna-fungsi-struktur-jenis-dan- }}$
proses-terbentuknya-rna-ribonucleic-
$\underline{\text { acid.html }}$

Figure 5. Student discussion page during learning genetic material topic in GC platform

The discussion held online in GC (as shown in Figure 5) provides a space for students to think when examining the opinions of their friends. The implementation of the blended-PBL makes students have wider opportunities especially the quantity of time so they have the opportunity to study at any time. The statement is line with some references that underlines with blended learning students can learn anywhere and anytime (Atef 
\& Medhat, 2015; Lalima \& Dangwal, 2017). This condition will overcome the weaknesses of PBL where PBL is often considered difficult to implement because of the limited time allocation of face-to-face learning (Blackwell \& Roseth, 2018; Marta, 2011; Roberto \& Ribeiro, 2011).

Moreover, learning by utilizing ICT is reported able to increase teaching and learning processes (Sangrà \& González-Sanmamed, 2010). Student ability to analyze the problem was also could be improved because they try to analyze problem during online discussion. Furthermore, students indirectly look for appropriate learning resources to support their understanding (Haghparast et al., 2014). This statement is in line with the other study that reported the learning activities supported by internet media can improve students' thinking skills (Corso \& Robinson, 2013).

Other studies also reported that the application of blended learning can improve learning experiences and learning outcomes (Wai \& Seng, 2014). Various studies also reported the benefits of applying blended learning in increasing the effectiveness of several cooperative learning (Adnan \& Bahri, 2018; Haghparast et al., 2014; Husamah, 2015). Not surprisingly, blended instruction is also considered as innovative learning that can help students improve their performance (Vernadakis, Giannousi, Derri, Michalopoulos, \& Kioumourtzoglou, 2012). Therefore, in order to improve the quality of learning in Indonesia, both Indonesian teachers and lecturers must also be able to design this kind of learning.

\section{CONCLUSION}

Based on the results of the study, students' CTS could be improved after the implementation of blendedPBL. Further analysis shows that before the implementation of the blended-PBL, students were not able to identify terms, consider definitions, and were unable to provide further explanation. In addition, students have difficulty in drawing conclusions from the discussion so that they cannot apply the concepts to different problems. After implementing the blended-PBL, students are able to develop their critical thinking skills so that they can provide simple explanations, build basic skills, provide further explanations, determine problem solving actions and can draw conclusions correctly.

In connection with the findings obtained, further research needs to be conduct with a wider number of samples and material coverage to get a more comprehensive information about the effectiveness of blendedPBL. In addition, further research is also expected to develop ideal blended-PBL framework and prepare a platform that supports the learning process according to the needs of the $21^{\text {st } C e n t u r y . ~}$

\section{REFERENCES}

Adnan, A., \& Bahri, A. (2018). Beyond effective teaching: Enhancing students' metacognitive skill through guided inquiry. In Journal of Physics: Conference Series (Vol. 954, p. 012022). doi: https://doi.org/10. 1088/1742-6596/954/1/012022

Afip, L. B. A. (2014). Motivating adult learners using blended learning in higher education institution. International Refereed Research Journal, 5(3), 35-42. Retrieved from https://www.researchgate.net/ publication/306240366

Akcay, B. (2009). Problem-based learning in science education. Journal of Turkish Science Education, 6(1), 26-36. Retrieved from https://www.pegem.net/dosyalar/dokuman/48116-20090429114931-04problembased-learning-in-science-education.pdf

Akyüz, H. I., \& Samsa, S. (2009). The effects of blended learning environment on the critical thinking skills of students. In Procedia - Social and Behavioral Sciences (Vol. 1, pp. 1744-1748). doi: https://doi.org/10.1 016/j.sbspro.2009.01.308

Ammann, D., Vignoli, Y., \& Kaap-Fröhlich, S. (2019). How can problem-based learning be realised in blended learning format? Contribution to the HoGe conference 2018 "Digital learning and teaching". International Journal of Health Professions, 6(1), 90-96. doi: https://doi.org/10.2478/ijhp-2019-0010

Atef, H., \& Medhat, M. (2015). Blended learning possibilities in enhancing education, training and development in developing countries: A case study in graphic design courses. TEM Journal, 4(4), 358365. Retrieved from http://www.temjournal.com/content/44/07/TemJournalNovember2015_358_365.pdf

Ates, O., \& Eryilmaz, A. (2011). Strengths and weaknesses of problem-based learning in engineeriing education: students' and tutors' perspectives. Buca Eğitim Fakültesi Dergisi, 28, 40-58. Retrieved from https://www.researchgate.net/publication/279682118\%0ASTRENGTHS

Batdi, V. (2014). A Meta-analysis study comparing problem based learning with traditional instruction. 
Electronic Journal of Social Sciences, 13(51), 346-365. Retrieved from http://search.ebscohost.com/lo gin. aspx?direct=true\&db=a9h\&AN=99171075\&site=ehost-live

Belecina, R. R., \& Ocampo, J. M. (2018). Effecting change on students' critical thinking in problem solving. EDUCARE: International Journal for Educational Studies International Journal for Educational Studies Article Timeline: Accepted, 10(102), 109-118. Retrieved from http://www.mindamas-journals.com/index. php/educare/article/viewFile/949/857

Blackwell, J. A., \& Roseth, N. E. (2018). Problem-based learning in a woodwind methods course: An action research study. Journal of Music Teacher Education, 28(1), 55-69. doi: https://doi.org/10.1177/1057083 718769262

Car, L. T., Myint Kyaw, B., Dunleavy, G., Smart, N. A., Semwal, M., Rotgans, J. I., ... Campbell, J. (2019). Digital problem-based learning in health professions: Systematic review and meta-analysis by the digital health education collaboration. Journal of Medical Internet Research, 21(2), 1-12. doi: https://doi.org/ 10.2196/12945

Chiang, C. L., \& Lee, H. (2016). The effect of project-based learning on learning motivation and problemsolving ability of vocational high school students. International Journal of Information and Education Technology, 6(9), 709-712. https://doi.org/10.7763/IJIET.2016.V6.779

Corso, R., \& Robinson, C.-H. (2013). Enhancing creative thinking abilities through the use of social media. International Journal of Knowledge, Innovation and Entrepreneurship, 1(1-2), 92-105. Retrieved from https://pdfs.semanticscholar.org/3daf/0e64ab35877140b64aa3722cde89b2453f50.pdf

Crowley, Ú. (2015). Review of critical thinking skills. AISHE, 7(3), 2641-2645. Retrieved from http://ojs.aishe.org/index.php/aishe-j/article/download/264/361

de Jong, N., Krumeich, J. S. M., \& Verstegen, D. M. L. (2017). To what extent can PBL principles be applied in blended learning: Lessons learned from health master programs. Medical Teacher, 39(2), 203-211. doi: https://doi.org/10.1080/0142159X.2016.1248915

Dewi, C. A. (2013). Pengaruh blended learning dalam pembelajaran berbasis masalah (PBL) terhadap hasil belajar mahasiswa IKIP Mataram pada materi pencemaran lingkungan. Prisma Sains: Jurnal Pengkajian IImu Dan Pembelajaran Matematika Dan IPA IKIP Mataram, 1(1), 1-11. doi: https://doi.org/ 10.33394/j-ps.v1i1.514

Dwyer, C. P., Hogan, M. J., \& Stewart, I. (2014). An integrated critical thinking framework for the 21st century. Thinking Skills and Creativity, 12, 43-52. https://doi.org/10.1016/j.tsc.2013.12.004

Ennis, R. H. (2011). The nature of critical thinking: An outline of critical thinking dispositions and abilities. Retrieved from http://faculty.education.illinois.edu/rhennis/ documents/TheNatureofCriticalThinking_517 11_000.pdf

Fauzi, A., \& Fariantika, A. (2018). Courses perceived difficult by undergraduate students majoring in biology. Biosfer: Jurnal Pendidikan Biologi, 11(2), 78-89. doi: https://doi.org/10.21009/biosferjpb.v11n2.78-89

Gholami, M., Moghadam, P. K., Mohammadipoor, F., Tarahi, M. J., Sak, M., Toulabi, T., \& Pour, A. H. H. (2016). Comparing the effects of problem-based learning and the traditional lecture method on critical thinking skills and metacognitive awareness in nursing students in a critical care nursing course. Nurse Education Today, 45, 16-21. doi: https://doi.org/10.1016/j.nedt.2016.06.007

Greiff, S., Niepel, C., \& Wüstenberg, S. (2015). 21st century skills: International advancements and recent developments. Thinking Skills and Creativity, 18, 1-3. doi: https://doi.org/10.1016/j.tsc.2015.04.007

Haghparast, M., Nasaruddin, F. H., \& Abdullah, N. (2014). Cultivating critical thinking through E-learning environment and tools: A review. In Procedia - Social and Behavioral Sciences (Vol. 129, pp. 527-535). Elsevier B.V. doi: https://doi.org/10.1016/j.sbspro.2014.03.710

Husamah, H. (2015). Blended project based learning: metacognitive awareness of biology education new students. Journal of Education and Learning, 9(4), 274-281. doi: https://doi.org/10.11591/edulearn.v9i4. 2121

Isabekov, A., \& Sadyrova, G. (2018). Project-based learning to develop creative abilities in students. In J. Drummer, G. Hakimov, M. Joldoshov, T. Köhler, \& S. Udartseva (Eds.), Vocational Teacher Education in Central Asia: Developing Skills and Facilitating Success (pp. 43-49). Cham: Springer International Publishing. doi: https://doi.org/10.1007/978-3-319-73093-6_4

Krishnan, S., Gabb, R., \& Vale, C. (2011). Learning cultures of problem-based learning teams. Australasian Journal of Engineering Education, 17(2), 67-78. doi: https://doi.org/10.1080/22054952.2011.11464057

Kumar, R., \& James, R. (2015). Evaluation of critical thinking in higher education in Oman. International Journal of Higher Education, 4(3), 33-43. doi: https://doi.org/10.5430/ijhe.v4n3p33 
Lai, E. (2011). Motivation: A literature review. Alwasy Learning. Retrieved from http://www.datec.org.uk/CHAT/ chatmeta1.htm

Lalima, L., \& Dangwal, K. L. (2017). Blended learning: An innovative approach. Universal Journal of Educational Research, 5(1), 129-136. doi: https://doi.org/10.13189/ujer.2017.050116

Lopes, R. M., Hauser-Davis, R. A., Oliveira, M. M., Pierini, M. F., de Souza, C. A. M., Cavalcante, A. L. M., ... Tinoca, L. A. da F. (2020). Principles of problem-based learning for training and professional practice in ecotoxicology. Science of The Total Environment, 702, 134809. doi: https://doi.org/10.1016/j.scitotenv.2 019.134809

Lukitasari, M, Handhika, J., \& Murtafiah, W. (2018). Higher order thinking skills: Using e-portfolio in projectbased learning. In Journal of Physics: Conference Series (Vol. 983, p. 012047). doi: https://doi.org/10. 1088/1742-6596/983/1/012047

Lukitasari, Marheny, Handhika, J., \& Murtafiah, W. (2016). Analisis kebutuhan e-portofolio berbasis metakognisi untuk meningkatkan ketrampilan Abad 21. In Proceeding Biology Education Conference (Vol. 13, pp. 93-96). Surakarta: FKIP UNS. Retrieved from https://jurnal.uns.ac.id/prosbi/article/view/ 5664/5032

Lukitasari, Marheny, \& Susilo, H. (2014). The improvement of students' ability to learn cell biology and discuss its application in live through the implementation of the Student Team Achievement Divisions (STAD) with Lesson Study (LS). In International Conference on Education and Language (ICEL) (Vol. 1, pp. 128-133). Bandar Lampung: Universitas Bandar Lampung. Retrieved from http://artikel.ubl.ac.id/ index.php/icel/article/view/272

Marra, R. M., Jonassen, D. H., \& Palmer, B. (2014). Why problem-based learning works: Theoretical foundations. Journal on Excellence in College Teaching, 25, 221-238. doi: https://doi.org/10.1111/j.16 00-0722.2010.00745.x

Marta, C. (2011). Using problem based learning to achieve lifelong learning. In The International Lifelong Learning Conference (pp. 465-471). Retrieved from http://icll2011.oum.edu.my/extfiles/pdf/Using Prob lem Based Learning to Achieve Lifelong Learning.pdf

Masek, A., \& Yamin, S. (2011). The effect of problem based learning on critical thinking ability: A theoretical and empirical review. International Review of Social Sciences and Humanities, 2(1), 215-221. Retrieved from https://pdfs.semanticscholar.org/4f47/2dc06281c45f765dc945599e92525b4c5679.pdf

Muis, A., \& Bahri, A. (2018). Respon guru dan siswa SMA terhadap penggunaan Quipper School dalam blended learning pada pembelajaran biologi. Biology Teaching and Learning, 1(2), 162-171. Retrieved from http://ojs.unm.ac.id/bt//article/view/8493/4932

Pagander, L., \& Read, J. (2014). Is Problem-Based Learning (PBL) an effective teaching method? A study based on existing reserch. Institutionen för Kultur och Kommunikation (Vol. 581). Retrieved from http:// www.diva-portal.org/smash/get/diva2:726932/FULLTEXT01.pdf

Ramdiah, S., Mayasari, R., Husamah, \& Fauzi, A. (2018). The effect of TPS and PBL learning models to the analytical ability of students in biology classroom. Asia-Pacific Forum on Science Learning and Teaching, 19(2). Retrieved from https://www.eduhk.hk/apfs/t/download/v19_issue2_files/ramdiah.pdf

Roberto, L., \& Ribeiro, C. (2011). The pros and cons of problem-based learning from the teacher's standpoint. Journal of University Teaching and Learning Practise, 8(1), 1-17. Retrieved from https://files. eric.ed.gov /fulltext/EJ940100.pdf

Sangrà, A., \& González-Sanmamed, M. (2010). The role of information and communication technologies in improving teaching and learning processes in primary and secondary schools. ALT-J, 18(3), 207-220. doi: https://doi.org/10.1080/09687769.2010.529108

Schmaltz, R. M., Jansen, E., \& Wenckowski, N. (2017). Redefining critical thinking: Teaching students to think like scientists. Frontiers in Psychology, 8(MAR), 2015-2018. doi: https://doi.org/10.3389/fpsyg.2017.00 459

Shimizu, I., Nakazawa, H., Sato, Y., Wolfhagen, I. H. A. P., \& Könings, K. D. (2019). Does blended problembased learning make Asian medical students active learners?: A prospective comparative study. BMC Medical Education, 19(147), 1-9. doi: https://doi.org/10.1186/s12909-019-1575-1

Siddiq, F., Scherer, R., \& Tondeur, J. (2016). Teachers' emphasis on developing students' digital information and communication skills (TEDDICS): A new construct in 21st century education. Computers \& Education, 92-93, 1-14. doi: https://doi.org/10.1016/j.compedu.2015.10.006

Suwono, H., \& Dewi, E. K. (2019). Problem-based learning blended with online interaction to improve motivation, scientific communication and higher order thinking skills of high school students. In AIP 
Conference Proceedings (Vol. 2081). doi: https://doi.org/10.1063/1.5094001

Temel, S. (2014). The effects of problem-based learning on pre-service teachers' critical thinking dispositions and perceptions of problem-solving ability. South African Journal of Education, 34(1), 1-20. doi: https:/l doi.org/10.15700/201412120936

Vernadakis, N., Giannousi, M., Derri, V., Michalopoulos, M., \& Kioumourtzoglou, E. (2012). The impact of blended and traditional instruction in students' performance. In Procedia Technology (Vol. 1, pp. 439443). doi: https://doi.org/10.1016/j.protcy.2012.02.098

Wai, C. C., \& Seng, E. L. K. (2014). Exploring the effectiveness and efficiency of blended learning tools in a school of business. In Procedia - Social and Behavioral Sciences (Vol. 123, pp. 470-476). Elsevier B.V. doi: https://doi.org/10.1016/j.sbspro.2014.01.1446

Woltering, V., Herrler, A., Spitzer, K., \& Spreckelsen, C. (2009). Blended learning positively affects students' satisfaction and the role of the tutor in the problem-based learning process: results of a mixed-method evaluation. Advances in Health Sciences Education, 14(5), 725-738. doi: https://doi.org/10.1007/s1045 9-009-9154-6

Yew, E. H. J., \& Goh, K. (2016). Problem-based learning: An overview of its process and impact on learning. Health Professions Education, 2(2), 75-79. doi: https://doi.org/10.1016/j.hpe.2016.01.004

Zubaidah, S., Corebima, A. D., \& Mistianah, M. (2015). Asesmen berpikir kritis terintegrasi tes essay. In Symbion: Symposium on Biology Education (pp. 200-213). Jogjakarta: Universitas Ahmad Dahlan. Retrieved from https://drive.google.com/file/d/0B4keDkb86kWpd0xRTjFIYVBjcEE/view 